\title{
Dose Dependent Effects of Dietary Immunostimulants on Rainbow Trout Immune Parameters and Susceptibility to the Parasite Ichthyophthirius Multifiliis
}

Rzgar M. Jaafar, Jakob Skov, Per W. Kania and Kurt Buchmann*

Section of Biomedicine, Department of Veterinary Disease Biology, Faculty of Life Sciences, University of Copenhagen

\begin{abstract}
Immunostimulants offered to fish in feed are considered to confer protection against various bacterial diseases but the effects on the antiparasitic response are largely unknown. Therefore effects of dietary $\beta$-1,3-glucan on innate immune parameters of juvenile rainbow trout Oncorhynchus mykiss and on susceptibility to the skin-parasitic ciliate Ichthyophthirius multifiliis (Ich) have been investigated. A basal diet (dry pelleted feed) was supplemented with $0 \%$ (control), $0.2 \%$ (low), $2.0 \%$ (medium), and $5.0 \%$ (high) of the $\beta-1,3$-glucan particulate insoluble algae glucan, paramylon, from Euglena gracilis. Fish (total 440) were divided into four groups each with 110 fish (kept in duplicate tanks of 55) and each diet was fed to two replicate groups at a daily feeding rate of $1.5 \%$ of fish biomass for 56 consecutive days. Liver and plasma sampling was performed at day 0 and after feeding with $\beta$-1,3-glucans for 14 , 28,42 , and 56 days and subsamples of fish were exposed to Ich at day 14 and 45 . Gene expression in trout liver was investigated by real-time GPCR and genes encoding immune molecules including acute phase proteins (SAA, hepcidin, and precerebellin), immunoglobulins (IgM and IgT), cytokine (IL-1ß), and lysozyme were investigated. In addition plasma lysozyme activity was recorded. At the start of the experiment the $5.0 \%$ glucan supplemented fish became more infected by parasites compared to control fish $(0.0 \%)$ but after 45 days feeding they obtained significantly fewer trophonts. Plasma lysozyme activity of fish fed low $(0.2 \%)$ and medium $(2.0 \%)$ glucan supplementation fluctuated, while high $(5.0 \%)$ glucan was associated with an elevation of lysozyme activity. Plasma lysozyme activity was positively correlated to expression of the lysozyme gene and to body mass of fish. Groups fed low (0.2\%) and medium $(2 \%)$ glucan diets showed a trend for down-regulation of immune relevant genes whereas the group fed with high $(5 \%)$ glucan showed a trend for up-regulation of genes especially the acute phase reactant SAA.
\end{abstract}

Keywords: Rainbow trout; Parasites; Immunostimulants; Betaglucan; Immune parameters; Lysozyme; SAA

\section{Introduction}

Immune stimulating abilities of $\beta$-glucans have received considerable attention and have been well studied in vertebrates. A wide range of studies demonstrated that $\beta$-1,3-glucans have a strong immune stimulating activity in a variety of vertebrates, such as mice [1], rats [2], chicken [3], pigs [4], sheep [5], cattle [6], horses [7], monkeys [8], and humans [9] and it has been reported that glucans raise both the cellular and the humoral immunity [4,10]. Also in aquaculture enterprises these compounds have been tested and have been successfully used to enhance resistance of fish and crustaceans against various bacterial infections [11-15]. Glucans can be isolated from a variety of sources and comprise schizophyllan from fungi (Schizophyllum commune) $[9,16]$, zymosan from yeast (Saccharomyces cerevisiae) [17-19], paramylon from algae (Euglena gracilis) [20], curdlan from bacteria (Alcaligenes faecalis) [21,22], and pustulan from lichens (crustaceous) (Umbilicaria pustulata) [23]. They all have a $(1,3)-\beta$-D-glucopyranosyl linked backbone, but their branching frequency, degree of polymerization, molecular weight and solubility differ which play a role in glucan-associated biological activity [24].

The skin parasitic ciliate Ichthyophthirius multifilis (Ich) causes ichthyophthiriasis in both wild and cultured host populations. The disease, commonly referred to as "white spot disease", may be fatal. The parasite infects gills, skin, eyes, and fins and cause severe epizootics in aquaria, hatcheries, and rearing ponds [25]. The effect of $0.2 \%$ yeast $\beta$-glucan on susceptibility of trout to Ich has previously been [26] but dose dependence has not been investigated. The present study was therefore undertaken in order to investigate the effects of $\beta-1,3$ glucan from the algae $E$. gracilis in different dosages $(0.0 \%, 0.2 \%, 2.0 \%$ and 5.0\%) administered in feed on some innate immune parameters of rainbow trout Oncorhynchus mykiss including susceptibility to the skin-parasitic ciliate.

\section{Materials and Methods}

\section{Fish}

Rainbow trout fry (Oncorhynchus mykiss) with an initial mean body weight of $167 \mathrm{mg}$ were obtained from the Bornholm salmon hatchery, Nexø, Bornholm where they had been hatched and reared under pathogen-free conditions. They were then brought to the experimental facilities at the University of Copenhagen. The fish were acclimated in the fish keeping facility in recirculated $200 \mathrm{~L}$ tanks equipped with internal filters (Eheim GmbH \& Co KG, Deizisau, Germany) at 11-13 ${ }^{\circ} \mathrm{C}$ for 12 weeks under a constant $12: 12 \mathrm{~h}$ light-dark cycle. Fish were fed with control pelleted trout feed (BioMar A/S, Denmark) (protein $46 \%$, fat $28 \%$, carbohydrate $16 \%$, and ash $7 \%$ ) at the rate of $1 \%$ of their

*Corresponding author: Kurt Buchmann, Section of Biomedicine, Department of Veterinary Disease Biology, Faculty of Life Sciences, University of Copenhagen, Stigbøjlen 7, DK-1870 Frederiksberg C., Denmark. Tel: +4535332700 , Fax: +4535332755; E-mail: kub@life.ku.dk

Received September 08, 2011; Accepted November 05, 2011; Published November 15, 2011

Citation: Jaafar RM, Skov J, Kania PW, Buchmann K (2011) Dose Dependent Effects of Dietary Immunostimulants on Rainbow Trout Immune Parameters and Susceptibility to the Parasite Ichthyophthirius Multifiliis. J Aquac Res Development S3:001. doi:10.4172/2155-9546.S3-001

Copyright: (c) 2011 Jaafar RM, et al. This is an open-access article distributed under the terms of the Creative Commons Attribution License, which permits unrestricted use, distribution, and reproduction in any medium, provided the original author and source are credited. 
biomass per day. Water (municipal water) was replenished daily and concentrations of nitrite, nitrate, ammonia and $\mathrm{pH}$ were measured on a regular basis (Merck Aquacant, Germany) $\left(\mathrm{NO}^{2}<10 \mathrm{mg} / \mathrm{l}, \mathrm{NO} 2\right.$ $<1 \mathrm{mg} / \mathrm{l}, \mathrm{NH} 3$ (not detectable), $\mathrm{pH}$ 7.2). No mortality was observed during the rearing period.

\section{Parasite culture}

A laboratory culture Ichthyophthirius multifiliis (Ich) was originally isolated from wild freshwater fish from the Danish stream Pøle river (Zealand). The parasite population was maintained through serial passage to naive rainbow trout in laboratory fish tanks for two years before experimental start.

\section{Experimental design and sampling protocol}

A total of 440 fish were used in the present study. Fish were randomly divided into 4 different groups, each represented by two duplicate groups of 55 fish. Groups were I, II, III, and IV (I 0.0\% control, II $0.2 \%$ low, III $2.0 \%$ medium, and IV $5.0 \%$ high). Each experimental diet was fed to two replicate groups at a rate of $1.5 \%$ of body weight per day for 56 consecutive days. Sampling was conducted at day 0 and at two weeks interval. No mortality was observed during the experimental period.

\section{Challenge infection}

Subsamples of 10 fish from each group ( 5 fish from each replicate tank) were exposed to challenge with Ich after being fed with $\beta$-glucan for 14 days (mean body weight $6 \mathrm{~g}$, mean body length $7 \mathrm{~cm}$ ) and for 45 days (mean body weight $12 \mathrm{~g}$, mean body length $11 \mathrm{~cm}$ ).

Fish from the different groups were exposed together to infective theronts (approximately 1000 theronts/l) in one fish tank (total volume 2501 ) in order to secure the same infection pressure and environmental conditions for all fish groups. Fish were tagged by fin-clipping in order to differentiate the different groups during parasite enumeration.

\section{Counting of trophonts}

Ten days following parasite exposure fish were anaesthetised by immersion into $50 \mathrm{mg} / \mathrm{l} \mathrm{MS} 222$ (Sigma-Aldrich, Denmark) and established trophonts were counted under a dissecting microscope (Olympus SZ30 at 9-40 $\times$ magnification), whereby the total number of visible trophonts (white spots) (fins and body skin) were enumerated.

\section{Sampling}

Fish were euthanized by immersion into an overdose of $100 \mathrm{mg} / \mathrm{l}$ MS222 (Sigma-Aldrich, Denmark). Blood samples for plasma lysozyme activity were taken from the caudal vessel by using $\mathrm{Na}$ - heparinised 25 $\mu \mathrm{l}$ and $50 \mu \mathrm{l}$ capillary pipettes (Hirschmann ${ }^{\circ}$ Laborgerate, Germany). The blood was centrifuged at $3000 \times g$ at $4{ }^{\circ} \mathrm{C}$ for $10 \mathrm{~min}$ and the plasma was stored at $-20^{\circ} \mathrm{C}$ until use. Samples of liver were taken for gene expression analysis and preserved in RNAlater (Sigma-Aldrich, Denmark). RNAlater samples were incubated for 24 hours at $4^{\circ} \mathrm{C}$ and then stored at $-20^{\circ} \mathrm{C}$ until use.

\section{Experimental fish diet}

Control feed was $1.5 \mathrm{~mm}$ pelleted dry feed based on fish-meal (protein $46 \%$, fat $28 \%$, carbohydrate $16 \%$, and ash $7 \%$ ) (BioMar $\mathrm{A} / \mathrm{S}$, Denmark) and the experimental diet was similarly composed but enriched with $\beta$-1,3-glucan from the algae E. gracilis by topcoating $\beta$-glucan to pellets with rapeseed oil $(30 \mathrm{ml} / \mathrm{kg}$ feed) during continuous spraying and stirring. Control feed was treated similarly without adding $\beta$-glucan [27]. Both control and experimental diets were prepared twice and stored for a maximum of four weeks at $4{ }^{\circ} \mathrm{C}$ during the experimental period (8 weeks).

\section{Measurement of lysozyme activity}

Plasma lysozyme activity was analysed by the turbidimetric assay described by Ellis [28], with a few modifications. A substrate suspension of Micrococcus lysodeikticus (Sigma-Aldrich, M3770, Denmark) $(0.2 \mathrm{mg} / \mathrm{ml})$ in sodium phosphate buffer $(0.06 \mathrm{M}, \mathrm{pH} 6.2)$ was prepared. Plasma was three-fold diluted in phosphate-buffered saline (PBS, $0.15 \mathrm{M}, \mathrm{pH}$ 7.4) (KU-Life Pharmacy, University of Copenhagen, Frederiksberg, Denmark). Flat bottomed MaxiSorp ${ }^{\text {tw }} 96$ wells microtiter plates (WVR, Denmark) were used in which $190 \mu \mathrm{l}$ of the substrate suspension was mixed with $10 \mu \mathrm{l}$ of diluted plasma samples in individual wells. Samples were analysed in duplicate wells. A reference sample was included in all plates within the same experiment to keep track of plate-to-plate variations. The absorbance at $450 \mathrm{~nm}$ was measured after 1 and $5 \mathrm{~min}$ incubation at room temperature using a microplate reader (Opsys MR, Dynex technologies). One unit was defined as $1 \%$ decrease of absorbance during an incubation time of 4 min: $\left.\left(\mathrm{OD}^{1 \mathrm{~min}}-\mathrm{OD}^{5 \mathrm{~min}}\right) / \mathrm{OD}^{1 \mathrm{~min}}\right)^{*} 100$.

\section{Isolation of RNA and cDNA synthesis}

Liver tissue samples were homogenised by sonication on ice with ARTEK Sonic Dismembrator model 300 (Bie \& Berntsen A/S, Herlev, Denmark), and total RNA was isolated using GenElute ${ }^{\text {ma }}$ kit (cat. no. RTN 350) from (Sigma-Aldrich, Denmark). DNase treatment using DNase I (Fermentas, Denmark) was performed immediately after purifying total RNA in order to eliminate genomic DNA. RNA concentration and purity was measured reading optical density at 260/280 nm using spectrophotometer NanoDrop 2000 (Thermo Scientific, Delaware, USA). The quality of the purified RNA was assessed visually by $1.5 \%$ agarose gel electrophoresis. Further, the kit TaqMan $^{\circ}$ Reverse Transcription (Applied Biosystems, USA) was used in the synthesis of cDNA from RNA. A master mix for cDNA synthesis was established by $10 \mathrm{x}$ RT-buffer, $\mathrm{MgCl}_{2} 250 \mathrm{mM}$, dNTP mix $50 \mu \mathrm{M}$, Primer $50 \mu \mathrm{M}$, RNase Inhibitor, Reverse Transcriptase, and RNase free water (Sigma-Aldrich, Denmark). In order to ensure complete removal of genomic DNA, five of the RNA samples were treated with same master mix except of substituting the reverse transcriptase with water, thus serving as no reverse transcriptase (RT minus) controls in the qPCR. Subsequently, all the samples of cDNA synthesized were diluted $1: 10$ in RNase free water and stored at $-20^{\circ} \mathrm{C}$ until further use.

\section{Quantitative real time PCR (qPCR)}

Quantitative PCR assays were performed using a Stratagene MX3000PTM real-time PCR system (AH diagnostics AS, Aarhus, Denmark). The cycling conditions were one cycle of predenaturation at $95{ }^{\circ} \mathrm{C}$ for $10 \mathrm{~min}$. This was followed by 45 cycles of denaturation at $95{ }^{\circ} \mathrm{C}$ for 30 second and combined annealing and elongation at $60{ }^{\circ} \mathrm{C}$ for 30 second with endpoint measurement. Reaction volumes were $12.5 \mu \mathrm{l}$, consisting of $6.25 \mu \mathrm{l}$ Brilliant ${ }^{\circ}$ II QPCR Master Mix (AH diagnostics A/S, Aarhus, Denmark), $0.4 \mu \mathrm{M}$ forward primer, $0.4 \mu \mathrm{M}$ reverse primer, $0.2 \mu \mathrm{M}$ probe, $2.5 \mu \mathrm{l}$ template and DNase free water (Invitrogen, Denmark) up to $12.5 \mu \mathrm{l}$. Primers and probes [29,30] are shown in Table 1. RT minus and negative controls were used for every plate setup. Elongation factor (ELF) 1- $\alpha$ was used as endogenous control (reference gene) [31]. A high Ct value indicates that the gene is expressed at a low level. Ct values was considered not recorded when the curves did not reach threshold value after 45 cycles. The levels of quantified mRNA product were detected by using specific TaqMan 


\begin{tabular}{|c|c|c|c|c|c|}
\hline Gene & $\begin{array}{l}\text { GenBank } \\
\text { Acc. No. }\end{array}$ & $\begin{array}{l}\text { Forward } \\
\text { primer }\end{array}$ & $\begin{array}{l}\text { Reverse } \\
\text { primer }\end{array}$ & Probe & $\begin{array}{c}\text { Size } \\
b p\end{array}$ \\
\hline ELF1- $\alpha$ & AF498320 & accetcctcttggtcgtttc & tgatgacaccaacagcaaca & gctgtgcgtgacatgaggca & 63 \\
\hline SAA & X99385 & gggagatgattcagggttcca & ttacgtccccagtggttagc & tcgaggacacgaggactcagca & 79 \\
\hline Hepcidin & AF281354 & gaggaggttggaagcattga & tgacgcttgaacctgaaatg & agtccagttggggaacatcaacag & 95 \\
\hline Precerebellin & AF192969 & tggtgttgctttgctgttgt & gccacttttggtttgctctc & atggttgagactcagacggagagtg & 116 \\
\hline $\lg M$ & S63348 & cttggcttgttgacgatgag & ggctagtggtgttgaattgg & tggagagaacgagcagttcagca & 95 \\
\hline $\lg T$ & AY870265 & agcaccagggtgaaacca & gcggtgggttcagagtca & agcaagacgacctccaaaacagaac & 73 \\
\hline IL-1 $\beta$ & AJ223954 & acattgccaacctcatcatcg & ttgagcaggtccttgtccttg & catggagaggttaaagggtggc & 91 \\
\hline Lysozyme & X59491 & gaaacagcctgcccaact & gtccaacaccacacgctt & atacccaggccaccaaccgcaacac & 188 \\
\hline
\end{tabular}

Table 1: Primers and probes including their GenBank accession numbers, product size and sequences. The efficiencies of all qPCR assays are within $100 \% \pm 5 \%$.

probes 6-FAM ${ }^{\mathrm{sm}}$ fluorophores (TAG Copenhagen, Denmark). In order to ensure specificity, all qPCR assays have been tested with SYBR Green $^{\circledR}$ and subsequent melting curve analysis.

\section{Data analysis}

The data from parasite enumeration and lysozyme activity were analysed by using SigmaStat version 11 (USA). In order to detect differences of mean parasite intensities and differences in lysozyme activities the Mann-Whitney Rank Sum Test and Student's t-test and were used, respectively. Survival of fish in various groups was compared using Kaplan-Meier survival plots and log rank test. Normality Test (Shapiro-Wilk) was used for evaluation of the normal distribution of data within each group. Correlation between plasma lysozyme and expression of the lysozyme gene in the liver of individual fish were analysed using the Spearman Rank Order correlation test. A probability level of 0.05 was applied in all tests. Gene expression data was interpreted according to the $2^{-\Delta \Delta \mathrm{Ct}}$ method [32]. In order to calculate $\Delta \mathrm{Ct}$ value, the threshold cycle $(\mathrm{Ct})$ of gene of interest was subtracted from the $\mathrm{Ct}$ of the reference gene of each sample at each sample point. $\Delta \mathrm{Ct}$ values of the $\beta$-glucan treated groups were subtracted from the average $\Delta \mathrm{Ct}$ of 10 fish of the control group $(0.0 \% \beta$-glucan $)$ in order to calculate the $\Delta \Delta \mathrm{Ct}$ value at each sample point. Further, values are fold increase or decrease in the target genes relative compared to control fish at each sample point. Positive values indicate up-regulation and negative values indicate down-regulation. Student's t-test was used to assess the differences between treated and non-treated groups. Data were considered significantly different when $\mathrm{p}<0.05$ and the fold change was at least 3 .

\section{Results}

Trophonts: All exposed fish obtained infection following exposure. Fish fed for 14 days with a high concentration (5.0\%) of $\beta$-glucan (group IV) obtained significantly more parasites (trophonts) $(\mathrm{p}<0.05)$ compared to control fish $(0.0 \%$, group I) whereas challenge infection after 45 days feeding with this high (5.0\%) glucan supplementation resulted in significantly fewer trophonts $(\mathrm{p}<0.05)$ compared to control fish (Figure 1).

\section{Plasma lysozyme activity}

Some variation was seen in all fish groups fed dietary $\beta$-glucan. However, in some groups and at some sample points glucan-treated fish showed a significantly increased level of lysozyme activity. Fish treated with a low $(0.2 \%)$ concentration of $\beta$-glucan for 14 days showed significant increases $(\mathrm{p}<0.01)$ relative to control fish. Activity in fish fed a medium glucan concentration $(2.0 \%)$ for 42 days was significantly increased $(\mathrm{p}<0.01)$. Group IV fish fed with a high concentration $(5.0 \%)$ showed significant increases at day $14(\mathrm{p}<0.01)$ and $56(\mathrm{p}<0.05)$ (Figure 2).

\section{Expression of investigated immune genes in the liver}

Genes encoding several immune molecules were investigated. These included acute phase proteins (SAA, hepcidin, and precerebellin), immunoglobulins (IgM and IgT), cytokine (IL-1 $\beta$ ) and lysozyme. Only gene expressions of more than a 3-fold increase or decrease were considered as significant regulations (Table 2). Group II (low, 0.2\%) and III (medium, 2.0\%) showed initially a non-significant downregulation of immune relevant genes and later a significant downregulation was seen with regard to the gene hepcidin of group III $(\mathrm{p}<0.05)$ at the last sample point (56 days of feeding with $\beta$-glucan) (Figure 3). Group IV (high, 5.0\%) showed a trend for up-regulation of immune relevant genes with a significant up-regulation $(\mathrm{p}<0.001)$ of the gene encoding SAA at day 28 of feeding with $\beta$-glucan (Figure 3 ). Following a moderate cytokine (IL-1 $\beta$ ) expression at the start of the experiment this signal molecule was down-regulated during the later phases in all groups (Table 2).

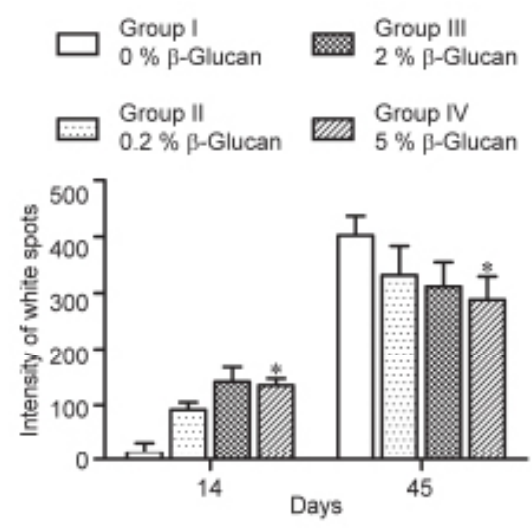

Figure 1: Intensity of Ichthyophthirius multifiliis trophonts in skin of rainbow trout. Parasites (white spots) were counted on the surface of whole fish 10 days after exposure to infective theronts in groups of fish fed for 14 and 45 days with different concentrations of $\beta$-glucan. *: Significant differences compared to control fish $(p<0.05)$. 
Citation: Jaafar RM, Skov J, Kania PW, Buchmann K (2011) Dose Dependent Effects of Dietary Immunostimulants on Rainbow Trout Immune Parameters and Susceptibility to the Parasite Ichthyophthirius Multifiliis. J Aquac Res Development S3:001. doi:10.4172/2155-9546.S3-001

Page 4 of 8

\begin{tabular}{|c|c|c|c|c|c|c|c|}
\hline Days & SAA & Hepcidin & Precerebellin & $\lg M$ & $\lg T$ & Lysozyme & IL-1 $\beta$ \\
\hline \multicolumn{8}{|c|}{ Group II, $0.2 \% \beta$-glucan } \\
\hline Day 0 & $\begin{array}{c}-1.88 \\
{[0.49 ; 0.61]}\end{array}$ & $\begin{array}{c}-2.22 \\
{[0.40 ; 0,77]}\end{array}$ & $\begin{array}{c}-1.09 \\
{[0.68 ; 2.13]}\end{array}$ & $\begin{array}{c}-1.02 \\
{[0.78 ; 1.56]}\end{array}$ & $\begin{array}{c}1.05 \\
{[0.84 ; 1.30]}\end{array}$ & $\begin{array}{c}1.79 \\
{[1.28 ; 2.50]}\end{array}$ & $\begin{array}{c}-9.25 \\
{[0.11 ; 0.11]}\end{array}$ \\
\hline Day14 & $\begin{array}{c}2.54 \\
{[1.77 ; 3.64]}\end{array}$ & $\begin{array}{c}1.74 \\
{[0.82 ; 3.71]}\end{array}$ & $\begin{array}{c}1.30 \\
{[1.08 ; 1.56]}\end{array}$ & $\begin{array}{c}1.02 \\
{[0.86 ; 1.22]}\end{array}$ & $\begin{array}{c}1.18 \\
{[0.94 ; 1.47]}\end{array}$ & $\begin{array}{c}-1.01 \\
{[0.85 ; 1.25]}\end{array}$ & $\begin{array}{c}-32.85 \\
{[0,03 ;-0.03]}\end{array}$ \\
\hline Day 28 & $\begin{array}{c}-1.30 \\
{[0.65 ;-1.07]}\end{array}$ & $\begin{array}{c}4.50 \\
{[2.28 ; 8.89]}\end{array}$ & $\begin{array}{c}1.22 \\
{[1.06 ; 1.40]}\end{array}$ & $\begin{array}{c}1.26 \\
{[1.07 ; 1.48]}\end{array}$ & $\begin{array}{c}1.36 \\
{[1.06 ; 1.75]}\end{array}$ & $\begin{array}{c}-1.56 \\
{[0.60 ; 0.70]}\end{array}$ & $\begin{array}{c}-6.22 \\
{[0.16 ; 0.16]}\end{array}$ \\
\hline Day 42 & $\begin{array}{c}-1.75 \\
{[0.51 ; 0.69]}\end{array}$ & $\begin{array}{c}-1.37 \\
{[0.57 ; 1.67]}\end{array}$ & $\begin{array}{c}-1.52 \\
{[0.61 ; 0.74]}\end{array}$ & $\begin{array}{c}1.01 \\
{[0.88 ; 1.16]}\end{array}$ & $\begin{array}{c}1.19 \\
{[1.05 ; 1.35]}\end{array}$ & $\begin{array}{c}-1.65 \\
{[0.55 ; 0.71]}\end{array}$ & $\begin{array}{c}1.53 \\
{[0.86 ; 2.72]}\end{array}$ \\
\hline Day 56 & $\begin{array}{c}-1.47 \\
{[0.57 ; 1.00]}\end{array}$ & $\begin{array}{c}-1.88 \\
{[0.47 ; 0.75]}\end{array}$ & $\begin{array}{c}-1.10 \\
{[0.78 ; 1.15]}\end{array}$ & $\begin{array}{c}1.70 \\
{[1.52 ; 1.90]}\end{array}$ & $\begin{array}{c}3.00 \\
{[2.46 ; 3.66]}\end{array}$ & $\begin{array}{c}2.11 \\
{[1.84 ; 2.42]}\end{array}$ & $\begin{array}{c}-19.08 \\
{[0.05 ; 0.05]}\end{array}$ \\
\hline \multicolumn{8}{|c|}{ Group III, $2 \% \beta$-glucan } \\
\hline Day 0 & $\begin{array}{c}-1.15 \\
{[0.66 ; 2.03]}\end{array}$ & $\begin{array}{c}5.52 \\
{[1.86 ; 16.37]}\end{array}$ & $\begin{array}{c}1.36 \\
{[1.00 ; 1.85]}\end{array}$ & $\begin{array}{c}1.54 \\
{[1.22 ; 1.94]}\end{array}$ & $\begin{array}{c}1.02 \\
{[0.81 ; 1.29]}\end{array}$ & $\begin{array}{c}1.59 \\
{[1.10 ; 2.30]}\end{array}$ & $\begin{array}{c}-1.02 \\
{[0.54 ;-0.21]}\end{array}$ \\
\hline Day14 & $\begin{array}{c}-2.58 \\
{[0.37 ; 0.41]}\end{array}$ & $\begin{array}{c}1.04 \\
{[0.66 ; 1.63]}\end{array}$ & $\begin{array}{c}1.00 \\
{[0.90 ; 1.12]}\end{array}$ & $\begin{array}{c}-1.07 \\
{[0.83 ; 1.11]}\end{array}$ & $\begin{array}{c}-1.27 \\
{[0.67 ; 1.05]}\end{array}$ & $\begin{array}{c}-1.68 \\
{[0.54 ; 0.70]}\end{array}$ & $\begin{array}{c}-19.27 \\
{[0.05 ;-0.08]}\end{array}$ \\
\hline Day 28 & $\begin{array}{c}1.37 \\
{[0.87 ; 2.17]}\end{array}$ & $\begin{array}{c}3.14 \\
{[1.64 ; 6.03]}\end{array}$ & $\begin{array}{c}1.07 \\
{[0.90 ; 1.28]}\end{array}$ & $\begin{array}{c}-1.01 \\
{[0.83 ; 1.32]}\end{array}$ & $\begin{array}{c}1.18 \\
{[0.99 ; 1.41]}\end{array}$ & $\begin{array}{c}-2.41 \\
{[0.39 ; 0.45]}\end{array}$ & $\begin{array}{c}-10.86 \\
{[0.09 ; 0.10]}\end{array}$ \\
\hline Day 42 & $\begin{array}{c}2.55 \\
{[1.24 ; 5.24]}\end{array}$ & $\begin{array}{c}1.03 \\
{[0.57 ; 1.86]}\end{array}$ & $\begin{array}{c}-1.13 \\
{[0.78 ; 1.05]}\end{array}$ & $\begin{array}{c}-1.20 \\
{[0.78 ; 0.92]}\end{array}$ & $\begin{array}{c}-1.33 \\
{[0.69 ; 0.83]}\end{array}$ & $\begin{array}{c}1.21 \\
{[1.03 ; 1.42]}\end{array}$ & $\begin{array}{c}2.11 \\
{[1.59 ; 2.80]}\end{array}$ \\
\hline Day 56 & $\begin{array}{c}-1.78 \\
{[0.52 ; 0.63]}\end{array}$ & $\begin{array}{c}\mathbf{- 5 . 7 9} \text { * } \\
{[0.17 ; 0.18]}\end{array}$ & $\begin{array}{c}-1.86 \\
{[0.52 ; 0.56]}\end{array}$ & $\begin{array}{c}-1.19 \\
{[1.05 ; 1.35]}\end{array}$ & $\begin{array}{c}1.64 \\
{[1.24 ; 2.17]}\end{array}$ & $\begin{array}{c}1.43 \\
{[1.15 ; 1.78]}\end{array}$ & $\begin{array}{c}-120.50 \\
{[0.01 ; 0.08]}\end{array}$ \\
\hline \multicolumn{8}{|c|}{ Group IV, $5 \%$ $\beta$-glucan } \\
\hline Day 0 & $\begin{array}{c}-2.41 \\
{[0.40 ; 0.43]}\end{array}$ & $\begin{array}{c}-1.47 \\
{[0.54 ; 1.54]}\end{array}$ & $\begin{array}{c}-1.26 \\
{[0.68 ; 1.02]}\end{array}$ & $\begin{array}{c}1.31 \\
{[1.08 ; 1.60]}\end{array}$ & $\begin{array}{c}-1.04 \\
{[0.81 ; 1.28]}\end{array}$ & $\begin{array}{c}-1.08 \\
{[0.74 ; 1.43]}\end{array}$ & $\begin{array}{c}3.34 \\
{[0.38 ; 28.95]}\end{array}$ \\
\hline Day14 & $\begin{array}{c}2.05 \\
{[2.05 ; 2.05]}\end{array}$ & $\begin{array}{c}2.00 \\
{[6.59 ; 0.38]}\end{array}$ & $\begin{array}{c}1.25 \\
{[1.11 ; 1.41]}\end{array}$ & $\begin{array}{c}1.61 \\
{[1.03 ; 1.31]}\end{array}$ & $\begin{array}{c}1.34 \\
{[1.11 ; 1.61]}\end{array}$ & $\begin{array}{c}1.48 \\
{[1.27 ; 1.73]}\end{array}$ & $\begin{array}{c}-10.09 \\
{[0.10 ; 0.10]}\end{array}$ \\
\hline Day 28 & $\begin{array}{c}12.69 * * * \\
{[8.75 ; 18.41]}\end{array}$ & $\begin{array}{c}1.69 \\
{[1.95 ; 0.90]}\end{array}$ & $\begin{array}{c}1.93 \\
{[1.62 ; 2.29]}\end{array}$ & $\begin{array}{c}-1.01 \\
{[0.88 ; 1.14]}\end{array}$ & $\begin{array}{c}1.21 \\
{[0.98 ; 1.49]}\end{array}$ & $\begin{array}{c}1.75 \\
{[1.38 ; 2.22]}\end{array}$ & $\begin{array}{c}-7.99 \\
{[0.12 ; 0.13]}\end{array}$ \\
\hline Day 42 & $\begin{array}{c}2.05 \\
{[; 187.7]}\end{array}$ & $\begin{array}{c}-1.60 \\
{[0.39 ; 0.24]}\end{array}$ & $\begin{array}{c}-1.06 \\
{[0.76 ;-1.39]}\end{array}$ & $\begin{array}{c}-1.09 \\
{[0.78 ; 1.18]}\end{array}$ & $\begin{array}{c}-1.68 \\
{[0.56 ; 0.64]}\end{array}$ & $\begin{array}{c}-1.33 \\
{[0.61 ; 1.30]}\end{array}$ & $\begin{array}{c}1.53 \\
{[1.15 ; 2.03]}\end{array}$ \\
\hline Day 56 & $\begin{array}{c}6.12 \\
{[3.09 ; 12.12]}\end{array}$ & $\begin{array}{c}3.27 \\
{[2.50 ; 1.42]}\end{array}$ & $\begin{array}{c}1.77 \\
{[1.28 ; 2.45]}\end{array}$ & $\begin{array}{c}1.65 \\
{[1.40 ; 1.94]}\end{array}$ & $\begin{array}{c}2.27 \\
{[1.95 ; 2.64]}\end{array}$ & $\begin{array}{c}2.04 \\
{[1.16 ; 3.60]}\end{array}$ & $\begin{array}{c}-52.74 \\
{[0.02 ; 0.02]}\end{array}$ \\
\hline
\end{tabular}

Table 2: Expression of immune genes in the liver of rainbow trout. Data is presented as a fold increase or decrease of genes in groups fed with $\beta$-glucan compared to the control group (fed $\beta$-glucan-free feed). Positive values indicate up-regulation and negative values indicate down-regulation. Confidence intervals are presented below in parentheses. Significant differences are in bold. ${ }^{*}: p<0.05,{ }^{* * *}: p<0.001$. The significant changes of hepcidin and SAA are presented graphically in Figure. 3 . Trends (although significant) are highlighted in grey.

\section{Correlation between plasma lysozyme activity and expression of lysozyme gene expression in liver}

The $\Delta \mathrm{OD}$ values of plasma lysozyme (over $4 \mathrm{~min}$ ) were correlated to Ct values of lysozyme gene transcripts of each individual fish in each group at each sample point. Positive correlations between plasma lysozyme activity and expression of the lysozyme gene (liver) were found in all groups investigated (Table 3). It should be noted that a high gene expression is reflected in a low $\mathrm{Ct}$ value. Therefore a positive correlation between plasma activity and gene expression level will be reflected in a negative $\mathrm{r}$-value between plasma lysozyme and $\mathrm{Ct}$ values as presented in Table 3 .

\section{Discussion}

The chemical composition of $\beta$-glucans vary considerably and the effects on fish may vary from one type of $\beta$-glucan to another [24] which may explain discrepancies with regard to $\beta$-glucan effects on fish occurring in the literature. The present study addresses the effects of a high-purity compound (paramylon) isolated from algae. In addition, different studies indicate that biological activity effect of the $\beta$-glucans can be influenced by various factors such as dosage, duration of administration, mode of application and target species. It is known that glucans in fish can modulate non-specific immune responses and enhance resistance of various fish towards pathogenic bacteria [11,13-15,33-35]. The present work showed that dietary glucan supplementation of feed for long-term administration

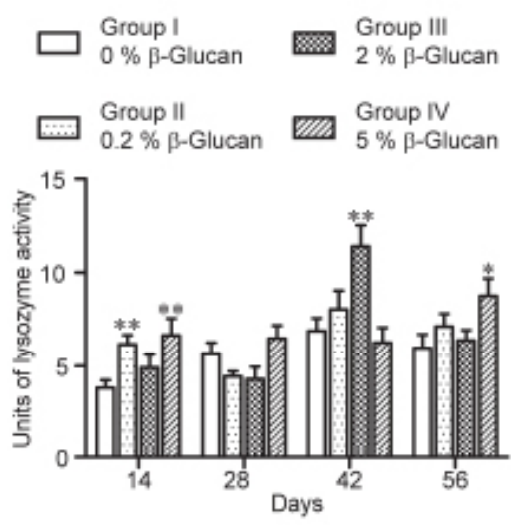

Figure 2: Lysozyme activity in plasma. The lysozyme activity in fish plasma was expressed as percentage change over 4 minutes in fish fed with different concentration of $\beta$-glucan. The $X$-axis represents days of feeding. 1 unit $\left.=\left(O D^{1 \mathrm{~min}}-O^{5 \mathrm{~min}}\right) / O^{1 \mathrm{~min}}\right) \times 100$. $\beta$-glucan fed groups were compared to control groups fed $\beta$-glucan-free feed. *: $(p<0.05),{ }^{* *}$ : $(p<0.01$.) 

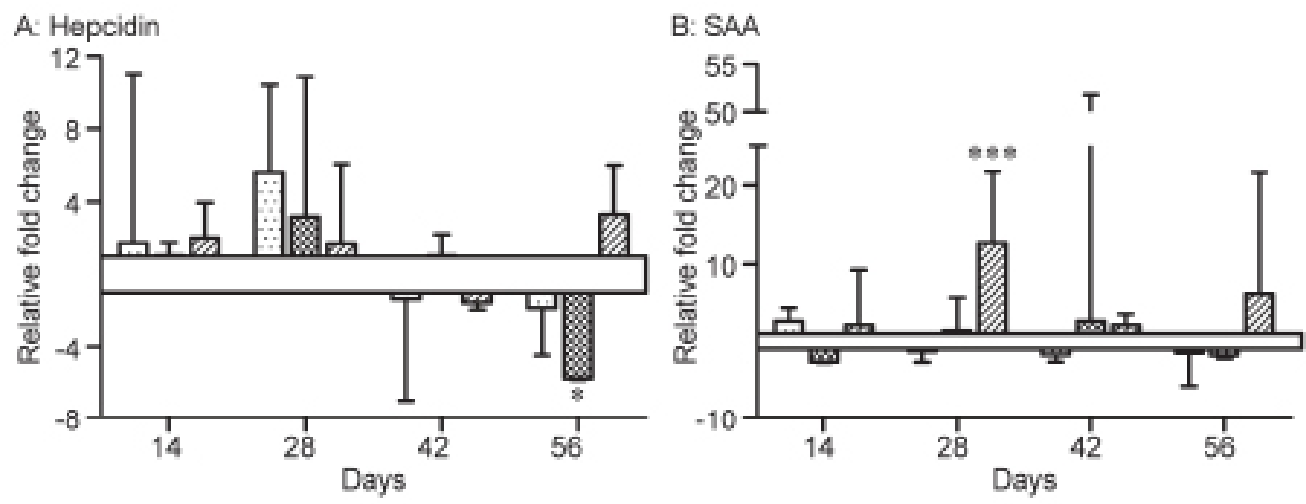

Figure 3: Real time quantitative PCR. A and B show the expression of the hepcidin and SAA in the liver, respectively. The X-axis represent days of feeding. Negative values indicate down-regulation and positive values indicate up-regulation. $\beta$-glucan fed groups were compared to control groups fed $\beta$-glucan-free feed. *: ( $p<0.05$ ), ***: $(p<0.0001)$.

\begin{tabular}{|c|c|c|c|c|c|c|c|c|}
\hline \multirow{2}{*}{$\begin{array}{c}\text { Day } \\
\text { of } \\
\text { feeding }\end{array}$} & \multicolumn{2}{|c|}{$\begin{array}{c}\text { Group I } \\
0 \% \quad \beta \text {-glucan }\end{array}$} & \multicolumn{2}{|c|}{$\begin{array}{c}\text { Group II } \\
0.2 \% \quad \beta \text {-glucan }\end{array}$} & \multicolumn{2}{|c|}{$\begin{array}{c}\text { Group III } \\
2 \% \quad \beta \text {-glucan }\end{array}$} & \multicolumn{2}{|c|}{$\begin{array}{c}\text { Group IV } \\
5 \% \quad \beta \text {-glucan }\end{array}$} \\
\hline & $r$ & $p$ & $r$ & $\mathbf{p}$ & $r$ & $p$ & $r$ & $\mathbf{p}$ \\
\hline 14 & -0.756 & 0.010 & -0.828 & 0.008 & -0.784 & 0.007 & -0.610 & ns \\
\hline 28 & -0.884 & 0.001 & -0.031 & ns & -0.701 & 0.020 & -0.554 & ns \\
\hline 42 & -0.267 & ns & -0.867 & 0.001 & -0.731 & 0.030 & -0.782 & 0.040 \\
\hline 56 & -0.291 & ns & -0.760 & 0.010 & -0.550 & ns & -0.857 & 0.010 \\
\hline
\end{tabular}

Table 3: Correlation (Spearman rank correlation) between plasma lysozyme activity and the expression of the lysozyme gene ( $\Delta$ Ct). Negative Spearman $r$-values reflect a positive correlation between the lysozyme activity and expression of the lysozyme gene. $r$ indicates the Spearman coefficient, $p$ indicates the p-value and ns indicates no significance $(p<0.05)$

(45 days) at a high dosage (5.0\%) in rainbow trout can confer some protection (expressed as a decrease in the number of skin trophonts) against ichthyophthiriasis. The protective mechanisms of fish against I. multifiliis infections have not been fully elucidated, but both innate and adaptive factors are involved [36,37]. It has been demonstrated that responses against gyrodactylids confer some cross-protection against Ich in rainbow trout [38], which suggests that innate response mechanisms are involved in this protection. Several studies have shown that antibodies play a role in the defence against Ich [39-41] but genes encoding acute phase reactants in the liver, such as serum amyloid A (SAA), have been found up-regulated in rainbow trout immunized intra-peritoneally with live Ich theronts [42] and it has been suggested that SAA may have a direct influence on the parasite [43]. However, it cannot be excluded that a number of other factors could confer immunity against Ich infection. Alishahi and Buchmann [44] showed that lysozyme levels in plasma were elevated following immunisation of rainbow trout by intra-peritoneal injection of live theronts. Thus, the link between Ich susceptibility and lysozyme activity may be worth analyzing. In the present study we found a significant increase in lysozyme activity in plasma and a trend for an elevated expression of most tested immune genes in fish exposed to a high (5.0\%) concentration of glucan in feed. Several authors have reported enhancement of lysozyme activity following administration of $\beta$-glucan $[15,26,35,45$ 49] but the lysozyme activity variation found in this study indicates that the regulation of this parameter is not straight forward. First of all the increase in body weight during the experiment was associated with an enhanced lysozyme production - also in control fish. This observation is in accordance with previous studies of salmonids [50].
Further, the activity in treated fish was elevated 2 weeks after initiation of feeding compared to control fish but showed subsequently a decline after 4 weeks whereafter lysozyme levels rose again and persisted at an elevated level after 6 to 8 weeks. The only exception was group III fed the medium glucan concentration $(2.0 \%)$ which reached a significant peak at week 6 whereafter it declined in week 8 . It seems that $\beta$-glucan, irrespective of dosage, stimulates the response, and subsequently leads to a temporary exhaustion until another increase may be seen. After a certain time the immune system seems to adapt to the continuous exposure to dietary $\beta$-glucan and sustain an increased production. Fish fed with a high (5.0\%) glucan concentration showed the same variation but still after 56 days showed significantly elevated lysozyme levels. There is still little information on how long the defence mechanism can be stimulated and the question may arise concerning how long time lysozyme elevation in plasma can persist after dietary $\beta$-glucan administration. Previous studies by Yoshida et al. [51] indicated that continuous long term oral administration of $\beta$-glucan $(0.1 \%$ for 45 days) resulted in higher lysozyme activity after 50 days. Paulsen et al. [47] showed that plasma lysozyme activity in Atlantic salmon decreased at day 21 after i.p. injection with $60 \mathrm{mg} / \mathrm{kg}$ of body weight of $\beta$-glucan (MacroGard ${ }^{\circ}$ ). In our study lysozyme gene transcription in liver differed among the groups receiving $\beta$-glucan. No significant differences in any group at any sample point were found, but a trend for a raised level in fish fed with high (5.0\%) glucan was seen. Strong positive correlations between the plasma lysozyme activity and lysozyme gene transcription (in liver) in the different groups were found which suggests that the lysozyme response is fast-acting. However, lysozyme production may occur in extra-hepatical organs and tissues as well and further studies 
should elaborate on the connection between lysozyme gene expression and effector molecules in fish.

The co-variation between the susceptibility to infection and lysozyme activity was not found clear-cut in our study. Thus, challenge infection after 14 days feeding with a high $(5.0 \%)$ glucan supplementation resulted in both significantly more parasites (trophonts) and lysozyme activity. In addition, fish fed with a low concentration $(0.2 \%)$ of glucan for 14 days showed significant increases in lysozyme activity in plasma whereas the parasite load was left unchanged. Therefore, the link between lysozyme levels in plasma and susceptibility to the skin-parasitic ciliate (I. multifiliis) infections may be influenced by additional factors. Fish fed a high (5.0\%) concentration of glucan for 45 days had significantly fewer trophonts compared to control fish. Therefore, both glucan concentration and administration time may interact with susceptibility after uptake in the fish.

Based on the present results of immune gene expression of trout liver, one can suggest that $\beta$-glucan molecules after intestinal uptake are distributed to other organs in fish. Hong et al. [52] reported that, in a murine model, orally administrated particulate $\beta$-1,3-glucans were taken up by intestinal macrophages and transported to spleen, lymph nodes, and bone marrow. Subsequently, within the macrophages large molecules of $\beta$-glucan were degraded and released as smaller soluble $\beta$-1,3-glucan fragments which were taken up in the bone marrow by granulocytes via the CR3 receptor. Also Rice et al. [53] found that water-soluble glucans (glucan phosphate, laminarin, and scleroglucan) translocate from the gastrointestinal tract into the systemic circulation in rats. This process may occur in fish as well [31,54-57].

The expression of immune relevant genes may be both dosedependent and influenced by the exposure time supporting Zhang et al. [57] who investigated the effect of laminaran $\beta$-glucan on trout at two different dosages. Fish treated with the high dose displayed significantly higher expression of IL-1 $\beta$ compared to fish treated with the low dose. Also Chettri et al. [31] found a glucan dose-dependent IL-1 $\beta$, IL-6 and TNF- $\alpha$ gene expression in head kidney leukocytes from rainbow trout in vitro. In the present study we found mostly down-regulation of the pro-inflammatory cytokine IL-1 during the later phases of glucan feeding in all groups. This may be explained by a necessary regulation of the inflammatory processes following extended exposure.

In the present work particulate, insoluble $\beta$-1,3-glucan from algae (Euglena gracilis), without any branching, with purity $\geq 98 \%$ and molecular weight $\sim 500,000 \mathrm{Da}$ (Sigma-Aldrich, Denmark) has been tested. $\beta$-1,3-glucan from $E$. gracilis has previously been shown to have positive effects in various tests such as hepatosplenomegaly assays, tumor challenge assays and toxicity tests in mice [58]. Furthermore, mice injected intravenously with this particular compound showed increased survival when challenged with Listeria monocytogenes [58]. Based on the results in the present work one can suggests that $\beta-1,3$ glucan at high (5\%) concentration may promise a positive effect as immunostimulant. However, the possible adverse effect of overdosing with $\beta$-glucans should be considered. Thus, Robertsen et al. [12] showed that fish injected with a high concentration $1800 \mu \mathrm{g} /$ fish of yeast glucan (Saccharomyces cerevisiae) and challenged one week later with Vibrio anguillarum sometimes expressed a higher mortality. It could be suggested that the high concentration leads to an overloading of the phagocytic cells with glucan particles temporarily decreased their phagocytosis ability.

The effect of this particular $\beta$-glucan may be weaker in comparison to other reports. Here it should be noted that some $\beta$-glucan preparations available are not chemically pure, whereby other chemical components in these preparations may be responsible, at least partly, for the reported effect. The cell wall of yeast (S. cerevisiae and Candida albicans) contains 4 classes of macromolecules such as mannoproteins, $\beta$-1,6-glucan, $\beta$-1,3-glucan, and chitin [59]. Thus, it has been shown $[60,61]$ that chitin possesses immunomodulatory effects in sea bream (Sparus aurata). Further, administration routes (oral, immersion, injection) may affect results. Oral administration of yeast glucan in channel catfish did not show any protection to Edwardsiella ictaluri [62], whereas injection of yeast glucan in channel catfish revealed increased protection [63]. In addition, the importance of the target pathogen (viral, bacterial, parasitic) should be framed. Our study showed only a protective effect against a skin-parasitic ciliate after highsupplementation feeding whereas other studies have shown a certain protection of rainbow trout against the microsporean parasite Loma salmonae independently of the dosage used [64]. Finally, the timing of glucan stimulation should be taken into consideration. Treatment before exposure induces a better protection of rainbow trout against $L$. salmonae compared to treatments after infection [65].

\section{Conclusions}

The results from the present investigation suggested that glucan effects on rainbow trout immune parameters are both time- and dosedependent. Thus, low and medium concentrations of $\beta$-1,3-glucan from algae (Euglena gracilis) in feed merely negligibly influenced the measured innate immune parameters and the antiparasitic response. However, a high concentration (5.0\%) offered over 45 days was found to be associated with a significantly reduced Ich-infection, a higher lysozyme production and a non-significant trend for an elevated expression of various immune genes. The gene encoding the acute phase reactant SAA was also found significantly upregulated in this fish group fed high supplementation for several weeks. Lysozyme activity in plasma was positively correlated with body mass of rainbow trout - also in control groups. It varied in all groups and was found significantly increased in some groups and at some sample point following feeding with $\beta$-1,3-glucan. This suggests that the concentration and exposure time of the immunostimulant may influence immune functions. However, due to the high market price of glucans the use $5 \%$ glucan supplementation (with best effects on all parameters) of aquaculture feed for extended periods may have a questionable profitability. Further, any adverse effects of such a high glucan concentration must be elucidated before steps are being taken for use of high glucansupplementation in commercial aquaculture feed products.

\section{Acknowledgments}

The work was supported by the Danish Fish Immunology Research Cente \& Network (DAFINET) (www. dafinet.dk) under the Danish Council for Strategic Research. Biomar A/S, Brande, Denmark, kindly supplied well analyzed experimental feed.

\section{References}

1. Suzuki I, Tanaka H, Kinoshita A Oikawa S, Osawa M, et al. (1990) Effect of orally administered $\beta$-glucan on macrophage function in mice. Int $\mathrm{J}$ Immunopharmacol 12: 675-684.

2. Babíček K, Čechová I, Simon RR, Harwood M, Cox DJ (2007) Toxicological assessment of a particulate yeast $(1,3 / 1,6)-\beta$-D-glucan in rats. Food Chem Toxicol 45: 1719-1730.

3. Chen KL, Weng BC, Chang MT, Liao YH, Chen TT, et al. (2008) Direct enhancement of the phagocytic and bactericidal capability of abdominal macrophage of chicks by $\beta-1,3-1,6$-glucan. Poult Sci 87 : 2242-2249. 
4. Li J, Xing J, Li D, Wang X, Zhao L, et al. (2005) Effects of $\beta$-glucan extracted from Saccharomyces cerevisiae on humoral and cellular immunity in weaned piglets. Arch Anim Nutr 59: 303-312.

5. Buddle BM, Pulford HD, Ralston M (1988) Protective effect of glucan against experimentally induced staphylococcal mastitis in ewes. Vet Microbiol 16: 6776.

6. Inchaisri C, Waller KP, Johannisson A (2000) Studies on the modulation of leucocyte subpopulations and immunoglobulins following intramammary infusion of $\beta 1$,3-glucan into the bovine udder during the dry period. J Vet Med B 47: 373-386.

7. Krakowski L, Krzyżanowski J, Wrona Z, Siwicki AK (1999) The effect of nonspecific immunostimulation of pregnant mares with 1,3/1,6 glucan and levamisole on the immunoglobulins levels in colostrum, selected indices of nonspecific cellular and humoral immunity in foals in neonatal and postnatal period. Vet Immunol Immunopathol 68: 1-11.

8. Reynolds JA, Kastello MD, Harrington DG, Crabbs CL, Peters CJ, et al. (1980) Glucan-induced enhancement of host resistance to selected infectious diseases. Infect Immun 30: 51-57.

9. Kubala L, Ruzickova J, Nickova K, Sandula J, Ciz M, et al. (2003) The effect of $(1 \rightarrow / 3)-\beta$-D-glucans, carboxymethylglucan and schizophyllan on human leukocytes in vitro. Carbohydr Res 338: 2835-2840

10. Xiao Z, Trincado CA, Murtaugh MP (2004) B-Glucan enhancement of T cell IFNy response in swine. Vet Immunol Immunopathol 102: 315-320.

11. Yano T, Mangindaan REP, Matsuyama H (1989) Enhancement of the resistance of carp Cyprinus carpio to experimental Edwardsiella tarda infection, by some $\beta-1,3-$ glucans. Nippon Suisan Gakkaishi 55: 1815-1819.

12. Robertsen B, Rørstad G, Engstad R, Raa J (1990) Enhancement of nonspecific disease resistance in Atlantic salmon, Salmo salar $\mathrm{L}$,, by a glucan from Saccharomyces cerevisiae cell walls. J Fish Dis 13: 391-400.

13. Siwicki AK, Anderson DP, Rumsey GL (1994) Dietary intake of immunostimulants by rainbow trout affects non-specific immunity and protection against furunculosis. Vet Immunol Immunopathol 41: 125-139.

14. Samuel M, Lam TJ, Sin YM (1996) Effect of Laminaran [ $\beta(1,3)-D-G l u c a n]$ on the protective immunity of blue gourami, Trichogaster trichopterus against Aeromonas hydrophila. Fish Shellfish Immunol 6: 443-454.

15. Misra CK, Das BK, Mukherjee SC, Pattnaik P (2006) Effect of long term administration of dietary $\beta$-glucan on immunity, growth and survival of Labeo rohita fingerlings. Aquaculture 255: 82-94.

16. Bot A, Smorenburg HE, Vreeker R, Pâques M, Clark AH (2001) Melting behavior of schizophyllan extracellular polysaccharide gels in the temperature range between 5 and $20^{\circ} \mathrm{C}$. Carbohydr Polymers 45: 363-372.

17. Manners DJ, Masson AJ, Patterson JC (1973) The Structure of a $\beta-(1 \rightarrow 3)-D$ glucan from yeast cell walls. Biochem J 135: 31-36.

18. Young SH, Robinson VA, Barger M, Whitmer M, Porter DW, et al. (2003) Exposure to particulate $1 \rightarrow 3$ - $\beta$-glucans induces greater pulmonary toxicity than soluble $1 \rightarrow 3-\beta$-glucans in rats. J Toxicol Environ Health 66: 25-38.

19. Frasnelli ME, Tarussio D, Chobaz-Péclat V, Busso N, So A (2005) TLR2 modulates inflammation in zymosan-induced arthritis in mice. Arthritis Res Ther 7: $370-379$.

20. Bäumer D, Preisfeld A, Ruppel HG (2001) Isolation and characterization of paramylon synthase from Euglena gracilis (Euglenophyceae). J Phycol 37: 3846.

21. Saito H, Tabeta R, Yoshioka Y, Hara C, Kiho T, et al. (1987) A high-resolution solid-state ${ }^{13} \mathrm{CNMR}$ study of the secondary structure of branched $(1 \rightarrow 3)-\beta-D$ glucans from fungi: evidence of two kinds of conformers, curdlan-type single-helix and laminaran-type triple-helix forms, as manifested from the conformation-dependent ${ }^{13} \mathrm{C}$ chemical shifts. Bull Chem Soc Jpn 60: 42674272.

22. Chuah CT, Sarko A, Deslandest Y, Marchessault RH (1983) Triple-Helical Crystalline structure of Curdlan and Paramylon Hydrates. J Macromol 16: 1375-1382.

23. Olafsdottir ES, Ingólfsdottir K (2000) Polysaccharides from lichens: structura characteristics and biological activity. Planta Med 67: 199-208.

24. Bohn JA, BeMiller JN (1995) (1-3)- $\beta$-D-glucans as biological response modifiers: a review of structure-functional activity relationships. Carbohydr Polymers 28: 3-14

25. Matthews RA (2005) Ichthyophthirius multifilis Fouquet and ichthyophthiriosis in freshwater teleosts. Adv Parasitol 59: 159-241.

26. Lauridsen JH, Buchmann K (2010) Effects of short- and long-term glucan feeding of rainbow trout on the susceptibility to Ichthyophthirius multifilis infections. Acta Ichthyol Piscat 40: 61-66.

27. Ortuño J, Cuesta A, Esteban MA, Meseguer J (2001) Effect of oral administration of high vitamin $C$ and $E$ dosages on the gilthead seabream (Sparus aurata $L$.) innate immune system. Vet Immunol Immunopathol 79: 167-180.

28. Ellis, AE (1990) Lysozyme assays. Techniques in Fish Immunology. SOS Publications, Fair Haven.

29. Raida KM, Buchmann K (2008) Development of adaptive immunity in rainbow trout, Oncorhynchus mykiss (Walbaum) surving an infection with Yersinia ruckeri. Fish Shellfish Immunol 25: 533-541.

30. Kania PW, Sprensen RR, Koch C, Brandt J, Kliem A, et al. (2010) Evolutionary conservation of mannan-binding lectin (MBL) in bony fish: Identification, characterization and expression analysis of three bona fide collectin homologues of $\mathrm{MBL}$ in the rainbow trout (Onchorhynchus mykiss). Fish Shellfish Immunol 29: 910-920.

31. Chettri JK, Raida MK, Andersen LH, Kania PW, Buchmann K (2011) PAMP induced expression of immune relevant genes in head kidney leukocytes of rainbow trout (Oncorhynchus mykiss). Dev Comp Immunol 35: 476-482.

32. Livak KJ, Schmittgen TD (2001) Analysis of relative gene expression data using real-time quantitative PCR and the $2^{-\Delta \Delta C}$ Tethod. Methods 25: 402-408.

33. Jeney G, Galeotti M, Volpatti D, Jeney Z, Anderson DP (1997) Prevention of stress in rainbow trout (Oncorhynchus mykiss) fed diets containing different doses of glucan. Aquaculture 154: 1-15.

34. Selvaraj V, Sampath K, Sekar V (2005) Administration of yeast glucan enhances survival and some non-specific and specific immune parameters in carp (Cyprinus carpio) infected with Aeromonas hydrophila. Fish Shellfish Immunol 19: 293-306.

35. Ai Q, Mai K, Zhang L, Tan B, Zhang W, et al. (2007) Effects of dietary $\beta-1,3$ glucan on innate immune response of large yellow croaker, Pseudosciaena crocea. Fish Shellfish Immunol 22: 394-402.

36. Buchmann K, Bresciani J (2001) An introduction to parasitic diseases of freshwater trout. DSR Publishers, Copenhagen.

37. Olsen MM, Kania PW, Heinecke RD, Skjoedt K, Rasmussen KJ, et al. (2011) Cellular and humoral factors involved in the response of rainbow trout gills to Ichthyophthirius multifiliis infections: Molecular and immunohistochemical studies. Fish Shellfish Immunol 30: 859-869.

38. Buchmann K, Lindenstrøm T, Sigh J (1999) Partial cross protection against Ichthyophthirius multifiliis in Gyrodactylus derjavini immunized rainbow trout. J Helminthol 73: 189-195.

39. Clark TG, Dickerson HW, Findly RC (1988) Immune response of channe catfish to ciliary antigens of Ichthyophthirius multifiliis. Dev Comp Immunol 12 581-594.

40. Clark TG, Dickerson HW (1997) Antibody-mediated effects on parasite behaviour: evidence of a novel mechanism of immunity against a parasitic protist. Parasitol Today 13: 477-480.

41. Sigh J, Buchmann K (2001) Comparison of immobilization assays and enzyme linked immunosorbent assays for detection of rainbow trout antibody-titres against Ichthyophthirius multifiliis Fouquet, 1876. J Fish Dis 24: 49-51.

42. Jørgensen LVG, Nemli E, Heinecke RD, Raida MK, Buchmann K (2008) Immune-relevant genes expressed in rainbow trout following immunisation with live vaccine against Ichthyophthirius multifiliis. Dis Aquat Organ 80: 189-197.

43. Gonzalez SF, Buchmann K, Nielsen ME (2007) Ichthyophthirius multifiliis infection induces massive up-regulation of serum amyloid $A$ in carp (Cyprinus carpio). Vet Immunol Immunopathol 115: 172-178.

44. Alishahi M, Buchmann K (2006) Temperature-dependent protection against Ichthyophthirius multifiliis following immunisation of rainbow trout using live theronts. Dis Aquat Organ 72: 269- 273.

45. Engstad RE, Robertsen B, Frivold E (1992) Yeast glucan induces increase 
Citation: Jaafar RM, Skov J, Kania PW, Buchmann K (2011) Dose Dependent Effects of Dietary Immunostimulants on Rainbow Trout Immune Parameters and Susceptibility to the Parasite Ichthyophthirius Multifiliis. J Aquac Res Development S3:001. doi:10.4172/2155-9546.S3-001

in lysozyme and complement-mediated haemolytic activity in Atlantic salmon blood. Fish Shellfish Immunol 2: 287-297.

46. Matsuyama H, Mangindaan REP, Yano T (1992) Protective effect of schizophyllan and scleroglucan against Streptococcus sp. infection in yellowtail (Seriola quinqueradiata. Aquaculture 101: 197-203.

47. Paulsen SM, Lunde H, Engstad RE, Robertsen B (2003) In vivo effects of $\beta$-glucan and LPS on regulation of lysozyme activity and mRNA expression in Atlantic salmon (Salmo salar L.). Fish Shellfish Immunol 14: 39-54.

48. Misra CK, Das BK, Pradhan J, Pattnaik P, Sethi S, et al. (2004) Changes in lysosomal enzyme activity and protection against Vibrio infection in Macrobrachium rosenbergii (De Man) post larvae after bath immunostimulation with $\beta$-glucan. Fish Shellfish Immunol 17: 389-395.

49. Bagni M, Romano N, Finoia MG, Abelli L, Scapigliati G, et al. (2005) Shortand long-term effects of a dietary yeast $\beta$-glucan (Macrogard) and alginic acid (Ergosan) preparation on immune response in sea bass (Dicentrarchus labrax). Fish Shellfish Immunol 18: 311-325.

50. Balfry SK, Iwama GK (2004) Observations on the inherent variability of measuring lysozyme activity in coho salmon (Oncorhynchus kisutch). Comp Biochem Physiol B Biochem Mol Biol. 138: 207-211.

51. Yoshida T, Kruger R, Inglis V (1995) Augmentation of non-specific protection in African catfish, Clarias gariepinus (Burchell), by the long-term ora administration of immunostimulants. J Fish Dis 18: 195-198.

52. Hong F, Yan J, Baran JT, Allendorf DJ, Hansen RD, et al. (2004) Mechanism by which orally administered $\beta$-1,3-glucans enhance the tumoricidal activity of antitumor monoclonal antibodies in murine tumor models. J Immunol 173: 797806

53. Rice PJ, Adams EL, Ozment-Skelton T, Gonzalez AJ, Goldman MP, et al. (2005) Oral delivery and gastrointestinal absorption of soluble glucans stimulate increased resistance to infectious challenge. J Pharmacol Exp Ther 314: 1079-1086.

54. Løvoll M, Fischer U, Mathisen GS, Bøgwald J, Ototake M, et al. (2007) The C3 subtypes are differentially regulated after immunostimulation in rainbow trout, but head kidney macrophages do not contribute to C3 transcription. Vet Immunol Immunopathol 117: 284-295.
55. Kim YS, Ke F, Zhang QY (2009) Effect of $\beta$-glucan on activity of antioxidant enzymes and $M x$ gene expression in virus infected grass carp. Fish Shellfish Immunol 27: 336-340.

56. Rodríguez I, Chamorro R, Novoa B, Figureueras A (2009) ß-Glucan administration enhances disease resistance and some innate immune responses in zebrafish (Danio rerio). Fish Shellfish Immunol 27: 369-373.

57. Zhang Z, Swain T, Bøgwald J, Dalmo RA, Kumari J (2009) Bath immunostimulation of rainbow trout (Oncorhynchus mykiss) fry induces enhancement of inflammatory cytokine transcripts, while repeated bath induce no changes. Fish Shellfish Immunol 26: 677-684.

58. Tusé D, Márquez L, Hokama LA (1992) Production of beta-1,3-glucan in Euglena. United States Patent No. 5,084,386.

59. Klis FM, De Groot D, Hellingwerf K (2001) Molecular organization of the cell wall of Candida albicans. Med Mycol 39: 1-8.

60. Esteban MA, Cuesta A, Ortuño J, Meseguer J (2001) Immunomodulatory effects of dietary intake of chitin on gilthead seabream (Sparus aurata L.) innate immune system. Fish Shellfish Immunol 11: 303-315.

61. Cuesta A, Meseguer J, Esteban MA (2004) Total serum immunoglobulin M levels are affected by immunomodulators in seabream (Sparus aurata L.). Vet Immunol Immunopathol 101: 203-210.

62. Duncan PL, Klesius PH (1996) Dietary immunostimulants enhance nonspecific immune responses in channel catfish but not resistance to Edwardsiella ictaluri. J Aquat Anim Health 8: 241-248.

63. Chen D, Ainsworth AJ (1992) Glucan administration potentiates immune defence mechanisms of channel catfish, Ictalurus punctatus Rafinesque. J Fish Dis 15: 295-304.

64. Guselle NJ, Markham RJF, Speare DJ (2006) Intraperitoneal administration of $\beta-1,3 / 1,6$-glucan to rainbow trout, Oncorhynchus mykiss (Walbaum), protects against Loma salmonae. J Fish Dis 29: 375-381

65. Guselle NJ, Markham RJF, Speare DJ (2007) Timing of intraperitonea administration of $\beta-1,3 / 1,6$-glucan to rainbow trout, Oncorhynchus mykiss (Walbaum), affects protection against the microsporidian Loma salmonae. J Fish Dis 30: 111-116.
This article was originally published in a special issue, Marine Biotechnology handled by Editor(s). Dr. Francesco buonocore, University of Tuscia, Italy 